\title{
Effects of Biosolids Application on Pasture and Grape Vines in South-Eastern Australia
}

\author{
David Nash, ${ }^{1}$ Craig Butler, ${ }^{1}$ Justine Cody, ${ }^{1}$ Michael St. J. Warne, ${ }^{2}$ \\ Mike J. McLaughlin, ${ }^{2,3}$ Dianne Heemsbergen, ${ }^{2,4}$ Kris Broos, ${ }^{2,5}$ Mike Bell, ${ }^{6}$ \\ Glenn Barry, ${ }^{7}$ Deb Pritchard, ${ }^{8}$ and Nancy Penny ${ }^{8,9}$
}

${ }^{1}$ Future Farming Systems Research Division, Department of Primary Industries, Ellinbank Centre, Ellinbank, VIC 3821, Australia

${ }^{2}$ Centre for Environmental Contaminants Research, Sustainable Agriculture Flagship, Commonwealth Scientific and Industrial Research Organisation, Urrbrae, SA 5064, Australia

${ }^{3}$ School of Agriculture, Food and Wine, The University of Adelaide, Adelaide, SA 5005, Australia

${ }^{4}$ Board of Authorisation of Plant Protection Products and Biocides, 6700 Wageningen, The Netherlands

${ }^{5}$ Flemish Institute for Technological Research, BE-2400 Mol, Flanders, Belgium

${ }^{6}$ Department of Primary Industries, Kingaroy, QLD 4610, Australia

${ }^{7}$ Department of Natural Resources and Mines, Indooroopilly, QLD 4068, Australia, Australia

${ }^{8}$ Curtin University of Technology, Muresk Institute, Northam, WA 6401, Australia

${ }^{9}$ Water Corporation of Western Australia, Leederville, WA 6007, Australia

Correspondence should be addressed to David Nash, david.nash@dpi.vic.gov.au

Received 22 December 2010; Accepted 4 February 2011

Academic Editor: Robert Edwin White

Copyright (c) 2011 David Nash et al. This is an open access article distributed under the Creative Commons Attribution License, which permits unrestricted use, distribution, and reproduction in any medium, provided the original work is properly cited.

\begin{abstract}
Biosolids were applied to a pasture and a vineyard in south-eastern Australia. At both sites, soil Cd, Cu, and $\mathrm{Zn}$ concentrations linearly increased with biosolids application rates although not to the extent of exceeding soil quality guidelines. Biosolids marginally increased soil $\mathrm{C}$ and $\mathrm{N}$ concentrations at the pasture site but significantly increased $\mathrm{P}$ concentrations. With lower overall soil fertility at the vineyard, biosolids increased C, N, and P concentrations. At neither site did biosolids application affect soil microbial endpoints. Biosolids increased pasture production compared to the unfertilised control but had little effect on grape production or quality. Interestingly, over the 3-year trial, there was no difference in pasture production between the biosolids treated plots and plots receiving inorganic fertiliser. These results suggest that biosolids could be used as a fertiliser to stimulate pasture production and as a soil conditioner to improve vineyard soils in this region.
\end{abstract}

\section{Introduction}

Biosolids are the solid or semisolid material produced from the biological treatment of sewage. As biosolids contain pathogens and contaminants that can adversely affect flora and fauna (including humans), management of the increasing amounts generated is a major international issue $[1,2]$. In the past, ocean dumping was an acceptable management option [3,4] but is now banned in some jurisdictions [5]. Given the organic nature of biosolids and the plant nutrients they contain, there is increasing emphasis on alternative disposal methods such as land application [6].

Composting can be used to reduce health risks from pathogenic organisms contained in biosolids $[7,8]$ prior to their application to land. However, depending on the concentrations initially present in the biosolids, metals and organic pollutants (such as pesticides, polychlorinated biphenyls, and polycyclic aromatic hydrocarbons) that remain after such treatments may adversely affect soil and human health $[9,10]$. Studies examining changes in soil health following biosolids addition to soil have been somewhat equivocal, because the apparently negative effects of organic chemicals and metals on soil biota may be outweighed by the positive effects organic matter additions [11-16].

In 2003, a series of field trials were established in south-eastern Australia as part of the Australian National Biosolids Research Program (NBRP). The NBRP aimed: 
TABle 1: Selected properties of surface soils $(0-100 \mathrm{~mm})$ at Pakenham and Mildura prior to their use in the National Biosolids Research Program, Victoria.

\begin{tabular}{lcc}
\hline Property ${ }^{1}$ & Pakenham site & Mildura site \\
\hline Texture & Very fine sandy clay loam & Sandy clay loam \\
pH $\left(1: 5 \mathrm{H}_{2} \mathrm{O}\right)$ & 5.6 & 8.0 \\
$\mathrm{pH}(1: 5 \mathrm{CaCl})$ & 5.0 & 8.3 \\
$\mathrm{EC}(\mathrm{dS} / \mathrm{m})$ & 0.16 & $<0.2$ \\
Total C $(\% \mathrm{w} / \mathrm{w})$ & 5.8 & 0.8 \\
Total $\mathrm{N}(\% \mathrm{w} / \mathrm{w})$ & 0.49 & 0.3 \\
Olsen $\mathrm{P}(\mathrm{mg} / \mathrm{kg})$ & 9 & 13 \\
$\mathrm{CPC} \mathrm{S}(\mathrm{mg} / \mathrm{kg})$ & 10 & 10 \\
Exch. $\mathrm{Ca}(\mathrm{meq} / 100 \mathrm{~g})$ & 5.4 & 3 \\
Exch. $\mathrm{Mg}(\mathrm{meq} / 100 \mathrm{~g})$ & 3.1 & 0.3 \\
Exch. $\mathrm{Na}(\mathrm{meq} / 100 \mathrm{~g})$ & 0.64 & 0.2 \\
Exch. $\mathrm{K}(\mathrm{meq} / 100 \mathrm{~g})$ & 0.5 & 0.3 \\
\hline
\end{tabular}

${ }^{1}$ For methods refer [26]: 4A1, 4B2, 3A1, 6B3, 7A5, 9C2, 10B3 modified using 1:4 extraction ratio and activated charcoal to remove organic S, 15D1/3 (Pakenham/Mildura).

(a) to quantify the potential human and environmental risks and benefits of applying biosolids to agricultural land, and (b) to develop biosolids quality guidelines for cadmium $(\mathrm{Cd})$, copper $(\mathrm{Cu})$, zinc $(\mathrm{Zn})$, and nutrients [17]. The NBRP program was predominantly field-based with 12 field sites in major agricultural regions of Australia and primarily focussed on grain production. Previous publications derived from the NBRP include models of the toxicity of $\mathrm{Cu}$ and $\mathrm{Zn}$ to micro-organisms [18] and wheat $[19,20]$, risks of soil-grain transfer of biosolid cadmium [21], comparisons of copper and zinc bioavailability to their soluble salts [22], and the application of phytotoxicity data to developing a new Australian framework for guiding biosolids applications [23].

South-eastern Australia has extensive areas of both pastoral grazing and perennial viticulture. Consequently, as part of the NBRP, biosolids were applied to pasture and vines in order to measure short-term $(<3$ years $)$ changes in production and soil quality. The biosolids were used as a fertiliser to stimulate pasture production and as a soil conditioner to improve vineyard soils [24]. This paper reports results from these studies.

\section{Materials and Methods}

Biosolids were applied to pasture at Pakenham $(-38.0932$, $145.5135)$ and grape vines at Mildura $(-33.9803,141.8757)$. The soil at the Pakenham site is classified as a Kurosol and the soil at the Mildura site as a Calcarosol according to the Australian Soil Classification [25]. Selected characteristics of the surface soils are presented in Table 1.

Three biosolids from different sources were used for the study (Table 2). The pasture trial had a randomised block design with two types of biosolids (B1-2), six biosolids treatments (T2-7), a control treatment (T1), and a mineral fertiliser treatment (T8). Each treatment was replicated three times (Rep 1-3) resulting in 48 plots per site. Plot sizes were $4 \times 9 \mathrm{~m}$ with a $1 \mathrm{~m}$ buffer zone between plots to minimise cross contamination. The Mildura trial in which only one biosolid was added was designed to incorporate the vine rows, and there were 48 experimental rows with two rows per treatment. In all other respects, the design was similar to that at Pakenham.

Biosolids were applied as multiples of the estimated nitrogen limiting biosolids application rate (NLBAR) [27]. At Pakenham plots (T2-T6) received one application of biosolids at the beginning of the trial, two weeks prior to planting the pasture. Biosolids were applied to mature grape vines at Mildura. At Mildura, there was an additional treatment of an annual application (T7) of biosolids at an NLBAR of 1.5. Pakenham did not receive an annual application of biosolids as incorporation into the soil was not possible without damaging the pasture. Hence, at Pakenham, T4 and T7 were the same, and no results for the T7 plots are presented. The biosolids application rates are shown in Table 3. The Pakenham trial commenced in 2004 and was monitored for three years, while the Mildura site was established in 2004 and monitored for two years. Climate data for both sites during the monitoring period are presented in Figure 1. Rainfall at Mildura was supplemented by drip irrigation as needed to prevent a moisture deficit adversely affecting crop production.

For the mineral fertiliser treatment (T8) at Pakenham, $330 \mathrm{~kg} / \mathrm{ha}$ urea was applied annually in 3 applications and $100 \mathrm{~kg} / \mathrm{ha}$ of a Superphosphate-Potash blend $(5.9 \%$ P, 16.6\% $\mathrm{K}, 7.3 \% \mathrm{~S}$ ) was applied in split applications annually. At Mildura, the design of the irrigation system did not allow for the isolation of the experimental plots from other sections of the vineyard. Consequently, there was no mineral fertiliser treatment (T8) at Mildura.

At Pakenham biosolids were measured using industrial scales and applied evenly to the plots before being incorporated into the soil using a tractor-mounted rotary hoe to a depth of $100 \mathrm{~mm}$. The site was sown with a commercial clover/ryegrass in May, 2004. At Mildura, a machineoperated spreader was used to spread the biosolids in August, 
Table 2: Properties of biosolids applied to pasture and grape vines in the National Biosolids Research Program, Victoria.

\begin{tabular}{lccc}
\hline & & Pakenham & Mildura \\
Property & South East Water & Yarra Valley Water & 2.5 \\
\hline Total N $(\%)$ & 0.88 & 0.60 & 210 \\
$\mathrm{NO}_{3}-\mathrm{N}(\mathrm{mg} / \mathrm{kg})$ & 420 & 590 & 720 \\
$\mathrm{NH}_{4}-\mathrm{N}(\mathrm{mg} / \mathrm{kg})$ & 160 & 15 & 0.83 \\
Total P $(\%)$ & 0.28 & 0.61 & 0.45 \\
Total K $(\%)$ & 0.18 & 0.33 & 0.52 \\
Total S $(\%)$ & 0.19 & 0.11 & 1.3 \\
Total Ca $(\%)$ & 0.49 & 7.1 & 0.32 \\
Total Mg $(\%)$ & 0.17 & 0.98 & 1.4 \\
Total Cd $(\mathrm{mg} / \mathrm{kg})$ & 0.70 & 0.70 & 220 \\
Total Cu $(\mathrm{mg} / \mathrm{kg})$ & 400 & 92 & 330 \\
Total $\mathrm{Zn}(\mathrm{mg} / \mathrm{kg})$ & 600 & 210 & 6.5 \\
pH & 4.4 & 8.3 & 79 \\
Solids $(\%)$ & 65 & 75 & 7.9 \\
EC $(\mathrm{dSm})^{\mathrm{b}}$ & 1.6 & 2.2 & 6.4 \\
Total C $(\%)$ & 8.7 & 6.4 & 16 \\
\hline
\end{tabular}

${ }^{\mathrm{a}}$ Report on a dry bases except for $\mathrm{pH}$ and EC.

${ }^{b}$ EC: Electrical conductivity $\left(40^{\circ} \mathrm{C}\right)$.

TABle 3: Treatments, application rates (in terms of Nitrogen Limiting Biosolids Application Rate (NLBAR) and mass (dry tonnes/ha)) and source of biosolids used in trials at Pakenham and Mildura.

\begin{tabular}{|c|c|c|c|c|}
\hline \multirow[b]{2}{*}{ Treatment plot number } & \multirow[b]{2}{*}{ NLBAR $^{\mathrm{a}}$} & \multicolumn{2}{|c|}{ Pakenham } & \multirow{2}{*}{$\begin{array}{c}\text { Mildura } \\
\text { Lower Murray Water }\end{array}$} \\
\hline & & South East Water & Yarra Valley Water & \\
\hline 1 (control) & 0 & 0 & 0 & 0 \\
\hline 2 & 0.5 & $25^{\mathrm{b}}$ & 29 & 9.5 \\
\hline 3 & 1.0 & 51 & 57 & 19 \\
\hline 4 & 1.5 & 77 & 86 & 28 \\
\hline 5 & 3.0 & 150 & 170 & 57 \\
\hline 6 & 4.5 & 230 & 260 & 85 \\
\hline 7 & $1.5^{\mathrm{c}}$ & $\mathrm{NA}^{\mathrm{d}}$ & NA & 28 \\
\hline 8 & \multicolumn{3}{|c|}{ Inorganic fertiliser treatment } & NA \\
\hline
\end{tabular}

${ }^{a}$ NLBAR: Nitrogen Limiting Biosolids Application Rate.

${ }^{\mathrm{b}}$ Application Rate (t/ha)

${ }^{\mathrm{c} A n n u a l}$ application of biosolids.

${ }^{\mathrm{d}} \mathrm{NA}$ : Not applicable.

2004. Biosolids were simultaneously spread to both rows within each plot. These biosolids were not incorporated as this could not be done without damaging the roots of the mature Cabernet Sauvignon grape vines established in 1998. The annual reapplication of biosolids at Mildura occurred in September, 2005.

At Pakenham, pasture sampling occurred seven times during the trial after a period of either simulated hay production (15 or 27 weeks) or grazing (6 weeks). Pasture was sampled on August 26, and November 17, 2004, July 19 and November 14, 2005, January 24, June 20, and September 12, 2006. Pastures were sampled by removing 25 random subsamples from within each plot $\left(5 \mathrm{~cm}^{2}\right.$ for each subsample). These samples were washed, dried at $65^{\circ} \mathrm{C}$, weighed, and ground prior to analysis. At strategic times and after sampling, pastures were mown to remove excess foliage.

At Mildura, grape vine petioles were sampled at $75 \%$ flowering (November) and grapes were sampled around harvest on March 1, 2005 and February 22, 2006, in keeping with local practice. Petioles and grapes were sampled from every sixth vine along each row within the plots. Subsamples of bunches of grapes were taken for analysis. Grape samples were stored frozen $\left(-20^{\circ} \mathrm{C}\right)$ until analysed. Grape yield $(\mathrm{t} / \mathrm{ha})$ was calculated using the berry weights of six $1 \mathrm{~m}$ sections of the plots, the row spacing and row length.

Total N, total $\mathrm{P}$, and concentrations of various metals $(\mathrm{K}$, $\mathrm{Ca}, \mathrm{Mg}, \mathrm{Na}, \mathrm{Cu}, \mathrm{Zn}, \mathrm{Mn}, \mathrm{Fe}, \mathrm{B}, \mathrm{Mo}, \mathrm{Co}, \mathrm{Al}, \mathrm{Cd}, \mathrm{Cr}, \mathrm{Pb}$, and $\mathrm{Ni})$ and a nonmetal $(\mathrm{S})$ were measured in the pasture samples 


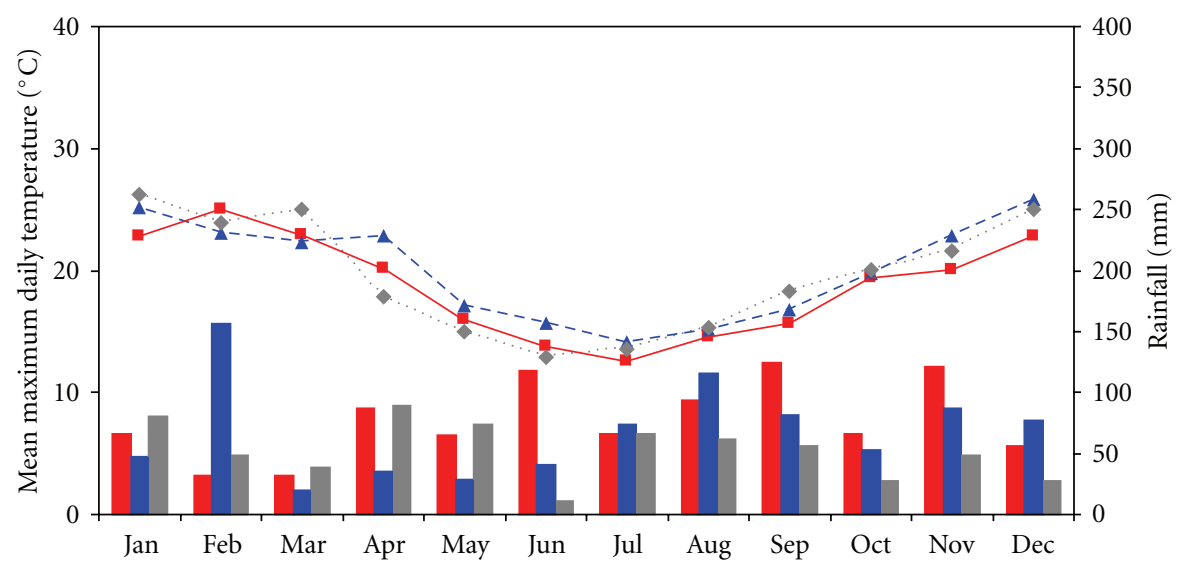

(a) Pakenham

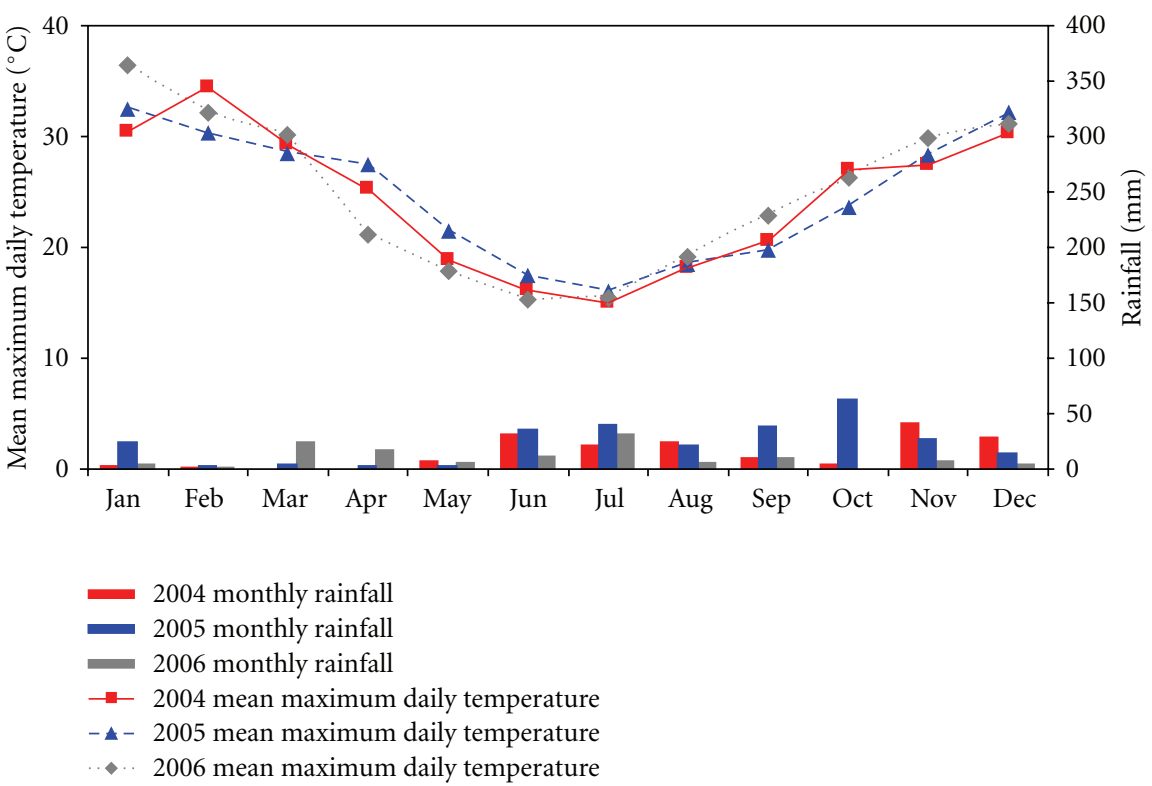

(b) Mildura

Figure 1: Mean monthly rainfall and mean daily maximum temperature for the Pakenham (a) and Mildura (b) sites used for the National Biosolids Research Program, Victoria.

from Pakenham and petiole samples using standard methods $[28,29]$. Grapes were analysed for trace metals as per the pasture and petiole samples and in addition moisture $\left(80^{\circ} \mathrm{C}\right)$, nitrate, 100 grape weight, Brix, $\mathrm{pH}$, titratable acidity, colour, and phenols using standard methods [30].

Pakenham soils were sampled postbiosolids application and annually (during harvest) by taking 30 randomly spaced soil cores $(0-10 \mathrm{~cm}$ depth). Mildura soils were sampled immediately after the application of the biosolids and at each harvest of the grapes (Year 1 and 2 ) by taking soil cores (0$10 \mathrm{~cm}$ depth) at every 6 th vine along each row within the plots. All soil samples were bulked, thoroughly mixed, dried, and ground to less than $2 \mathrm{~mm}(1 \mathrm{~B} 1,[26])$ before subsamples were analysed for total C (6B3, [26]), total P [31] and total $\mathrm{N}$ (7A5, [26]), Colwell P (9B2, [26]), nitrate-N and ammonia$\mathrm{N}(7 \mathrm{C} 2,[26])$ and $\mathrm{pH}(4 \mathrm{~B} 2,[26])$.
Microbial endpoints, substrate-induced nitrification (SIN) $[32,33]$, and substrate induced respiration (SIR) were also measured on soil samples. The SIR was measured based on the OECD guidelines [32] with some modifications [18]. After a preincubation of 14 days at $20^{\circ} \mathrm{C}$ in darkness at $50 \%$ maximum water holding capacity (MWHC), soil samples (equivalent of $10 \mathrm{~g}$ dry soil) were amended with ${ }^{14} \mathrm{C}$-labelled (a traceable radioactive isotope of carbon) glucose solution $\left(125 \mathrm{~Bq} / \mathrm{g}\right.$ of soil) to $5000 \mu \mathrm{g} \mathrm{C} \mathrm{g} \mathrm{g}^{-1}$ soil. After addition of the glucose solution, the samples were at $60 \pm 5 \%$ of their MWHC. The soil samples were immediately transferred into sealed containers $(250 \mathrm{~mL})$ containing a vial with $3 \mathrm{~mL}$ $1 \mathrm{M} \mathrm{NaOH}$, which acts as a trap for the carbon dioxide $\left(\mathrm{CO}_{2}\right)$ produced from microbial respiration. Each sample was incubated in darkness at $20^{\circ} \mathrm{C}$ for six hours, after which time $1 \mathrm{~mL}$ of the $\mathrm{NaOH}$ was removed and added to $10 \mathrm{~mL}$ of 
scintillation cocktail (XT Gold) for radioactivity determination by beta counting (liquid scintillant beta counter LSBC). The rate of ${ }^{14} \mathrm{CO}_{2}-\mathrm{C}$ production per gram of dry soil per hour was calculated from the sample radioactivity.

Agronomic and soils data were examined using analysis of variance (ANOVA). This was performed on plot means using Genstat 9.1 Edition software [34]. Where significant differences between data are discussed, these refer to treatment means at a $95 \%$ confidence interval. Where data exhibited a log-normal distribution, least significant ratios at the 95\% level are quoted in tables instead of the least significant difference at the $95 \%$ level. In such cases, if the ratio of the two means is greater than the stated ratio, there is a significant difference at the $95 \%$ confidence limit. Linear regressions were fitted to agronomic data in the biosolids trials where relationships were observed.

\section{Results and Discussion}

3.1. Pakenham. The application of South East Water and Yarra Valley biosolids at Pakenham appeared to raise soil $\mathrm{pH}$ compared to the untreated and fertiliser controls in which the $\mathrm{pH}$ in $\mathrm{CaCl}_{2}$ was 4.9. However, there was no consistent trend with biosolids application rate as the results were highly variable between plots, more so than between years.

Compared to the unfertilised control, biosolids applications increased the concentrations of $\mathrm{Cd}$ in the soils above the 1.0 NLBAR biosolids application rate for South East Water biosolids and above the 1.5 NLBAR biosolids application rate for Yarra Valley Water biosolids, increased concentrations of soil $\mathrm{Cu}$ above 1.0 NLBAR and increased soil $\mathrm{Zn}$ concentrations at all biosolids application rates $(P<.05)$ (Table 4$)$. The concentrations of $\mathrm{Cu}$ and $\mathrm{Zn}$ in soils treated with South East Water biosolids were generally higher than those treated with Yarra valley water biosolids in keeping with the respective metal concentrations in the biosolids. There were positive linear relationships between the concentration of $\mathrm{Cd}, \mathrm{Cu}$, and $\mathrm{Zn}$ in soils and increasing biosolids application rates $\left(r^{2}>0.90\right)$. All soil metal concentrations were below the current receiving soil contaminant limits (RSCL) of $100 \mathrm{mg} / \mathrm{kg}$ for $\mathrm{Cu}, 200 \mathrm{mg} / \mathrm{kg}$ for $\mathrm{Zn}$ and $1 \mathrm{mg} / \mathrm{kg}$ for Cd [27].

Immediately after the application of biosolids, compared to the unfertilised control, soil $\mathrm{C}$ and $\mathrm{N}$ only increased in Yarra valley biosolids plots at the 1.5 NLBAR $(P<$ .05 ) biosolids application rate and then only marginally. Presumably this result reflects the relatively high soil $\mathrm{C}$ and $\mathrm{N}$ concentrations $(58 \mathrm{~g} \mathrm{C} / \mathrm{kg}$ and $4.9 \mathrm{~g} \mathrm{~N} / \mathrm{kg})$ in the soil prior to biosolid applications and is consistent with other similar studies [35]. Compared to the unfertilised control, the application of South East Water biosolids increased soil total $\mathrm{P}$ concentrations at 1.0, 3.0 and 4.5 NLBAR while Yarra Valley Water biosolids applications increased P concentrations at all biosolids application rates. The increase in total $\mathrm{P}$ concentrations was generally in line with the rates of biosolids addition (Figure 2) and reflects the considerable quantity of $\mathrm{P}$ added to soil in biosolids (c.a. 143 and $348 \mathrm{~kg}$ $\mathrm{P} /$ ha at 1 NLBAR for South East Water and Yarra Valley Water biosolids, resp.). Interestingly, plant-available $\mathrm{P}$ measured

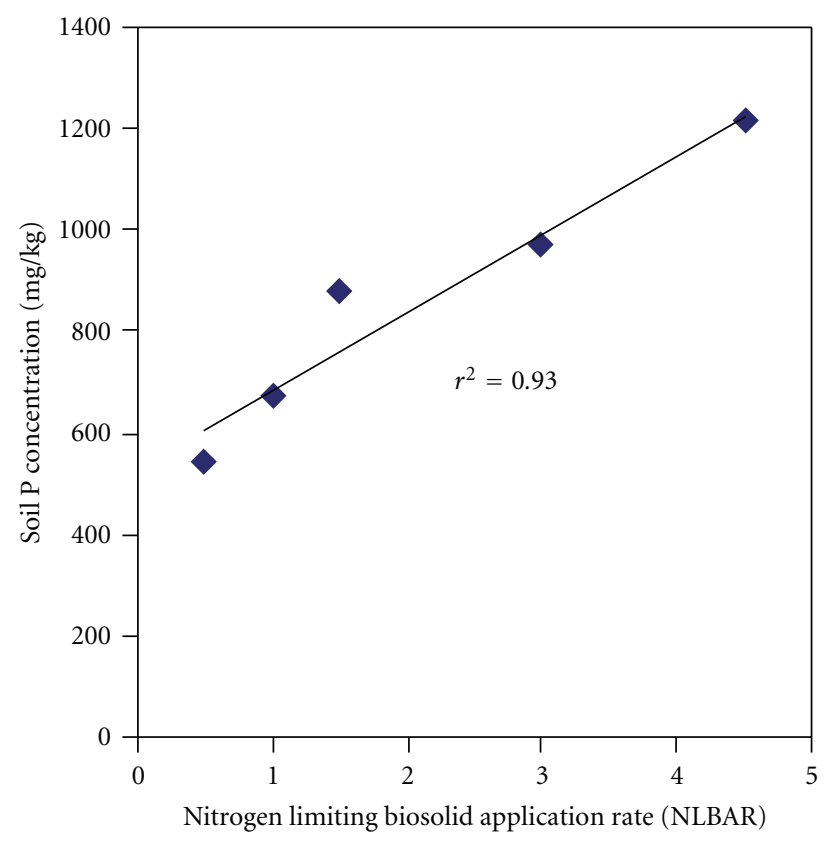

Figure 2: Mean soil total phosphorus concentrations versus biosolids application rates immediately after biosolids were applied at the Pakenham site in 2004.

using the Colwell method (Colwell 1963) also increased with biosolids application with the control rated "medium" [36] at $46 \mathrm{mg} / \mathrm{kg}$ and the 4.5 NLBAR treatment rated "High" at $390 \mathrm{mg} / \mathrm{kg}$ [36] even for crops with a high P demand (i.e., vegetables).

The application of biosolids at Pakenham appeared to have little effect on microbial function. Across all biosolids, application rates, and over the three sampling events from 2004 to 2006, there were only four instances when, compared to the unfertilised control, biosolids application may have affected SIR, and the results were equivocal. For example, compared to the unfertilised control SIR increased, where South East Water biosolids were applied at 1.0 and 4.5 NLBAR for soils sampled immediately after application $(P<$ $.05)$. But for the 3.0 NLBAR application at the same sampling time, SIR decreased $(P<.05)$. In a few instances, compared to inorganic fertiliser, biosolids applications resulted in slightly lower SIR although again these results appear to reflect the variability in these tests rather than any real trend in the data. The results of the SIN testing were similarly inconclusive although primarily as a result of limitations in the method. Compared to the unfertilised control, SIN did not change, due to $100 \%$ of the added nitrogen substrate being used in all cases.

Over the seven sampling events from 2004 to 2006, biosolids increased pasture dry matter production compared to the unfertilised control. There was no overall difference between biosolids and the inorganic fertiliser treatment $(P>$ $.05)$ pasture yields. There was a positive linear relationship between mean pasture dry matter production and biosolids application rate $\left(r^{2}=0.89\right.$; Figure 3$)$. However, this was not always the case for every sampling event. 
TABLe 4: Soil Cd, $\mathrm{Cu}$, and Zn concentrations $(\mathrm{mg} / \mathrm{kg})$ at Pakenham immediately after the application of biosolids in 2004.

\begin{tabular}{|c|c|c|c|c|c|c|c|}
\hline \multirow[b]{2}{*}{ Treatment } & \multirow[b]{2}{*}{ NLBAR $^{\mathrm{a}}$} & \multicolumn{2}{|c|}{ Soil Cd concentration } & \multicolumn{2}{|c|}{ Soil Cu concentration } & \multicolumn{2}{|c|}{ Soil Zn concentration } \\
\hline & & South East Water & Yarra Valley Water & South East Water & Yarra Valley Water & South East Water & Yarra Valley Water \\
\hline 1 (control) & 0.0 & \multicolumn{2}{|c|}{0.17} & \multicolumn{2}{|c|}{9.6} & \multicolumn{2}{|c|}{9.1} \\
\hline 2 & 0.5 & 0.17 & 0.17 & 12.2 & 8.4 & $16.0^{*}$ & $14.3^{*}$ \\
\hline 3 & 1.0 & 0.18 & 0.17 & 11.0 & 10.5 & $21.5^{*}$ & $17.2^{*}$ \\
\hline 4 & 1.5 & $0.25^{*}$ & 0.18 & $14.7^{*}$ & $15.4^{*}$ & $27.7^{*}$ & $23.9 *$ \\
\hline 5 & 3.0 & $0.24^{*}$ & $0.21^{*}$ & $30.8^{*}$ & $17.0^{*}$ & $61.6^{*}$ & $24.8^{*}$ \\
\hline 6 & 4.5 & $0.27 *$ & $0.21^{*}$ & $39.8^{*}$ & $21.1^{*}$ & $74.6^{*}$ & $37.4^{*}$ \\
\hline 8 (fertiliser) & 1.0 & \multicolumn{2}{|c|}{0.16} & \multicolumn{2}{|c|}{8} & \multicolumn{2}{|c|}{7.8} \\
\hline \multicolumn{2}{|l|}{ 1.s.r. ${ }^{\mathrm{b}}(P<.05)$} & \multicolumn{2}{|c|}{1.23} & \multicolumn{2}{|c|}{1.46} & \multicolumn{2}{|c|}{1.46} \\
\hline $\mathrm{RSCL}^{\mathrm{c}}$ & & \multicolumn{2}{|c|}{1.0} & \multicolumn{2}{|c|}{100} & \multicolumn{2}{|c|}{200} \\
\hline
\end{tabular}

${ }^{a}$ Nitrogen limiting biosolids application rate.

${ }^{b}$ Least significant ratio-if the mean divided by the control value is greater than this ratio then the difference is statistically significant $(P<.05, *)$.

${ }^{\mathrm{c} R S C L}$ : receiving soil contaminant limit [27].

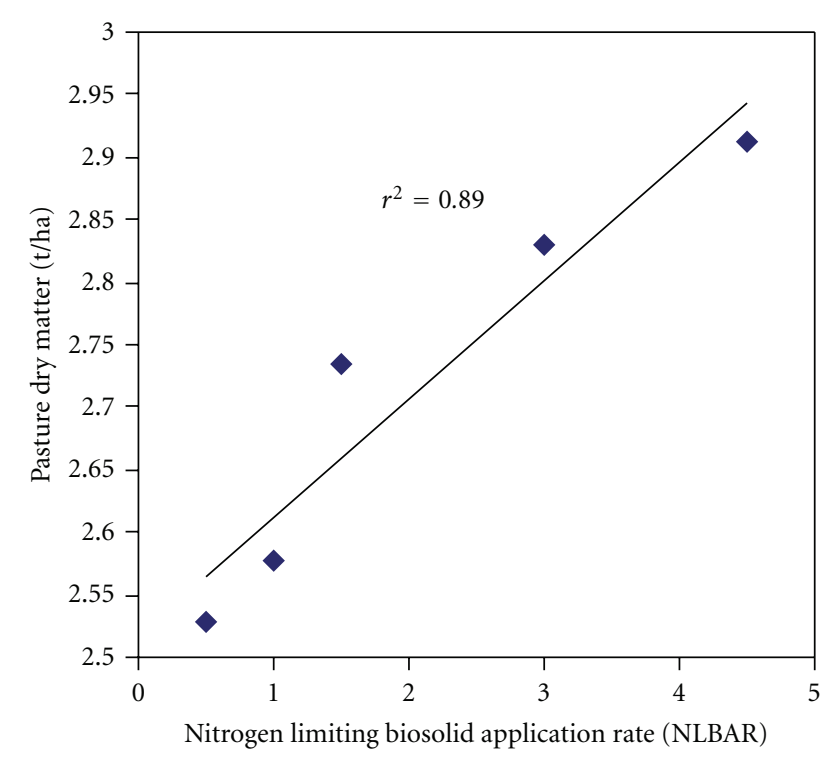

Figure 3: Mean pasture dry matter production versus biosolid application rate at Pakenham site from 2004 to 2006.

Pasture dry matter production at Pakenham from 20042006 is presented in Table 5. The first season represented the growth of a field crop such as hay. The first sampling was at 15 weeks after sowing on August 25, 2004. Compared to the unfertilised control, with the exception of the South East Water 0.5 NLBAR plots, pasture dry matter production in biosolids treatments and inorganic fertiliser treatments increased $(P<.05)$. Compared to the unfertilised control, pasture dry matter production increased by over $100 \%$ at the highest application rate of Yarra Valley Water biosolids. Overall, at the first sampling, biosolids were at least, if not more effective than fertiliser for increasing dry matter production $(P<.05)$.

After 27 weeks of growth, the second sampling of the simulated hay crop occurred on November 17, 2004. The extended growing period explains why the second sampling yielded the highest dry matter production
(Table 5-7.38 t/ha in unfertilised control plots). Compared to the unfertilised control, at the second sampling pasture dry matter increased at the three highest South East Water biosolid application rates and at 4.5 NLBAR for Yarra Valley Water biosolids $(P<.05)$. The application of inorganic fertiliser did not increase pasture production compared to the unfertilised control $(P<.05)$ although there was also no significant difference between pasture dry matter in biosolids treatments compared to inorganic fertiliser treatments $(P>$ $.05)$. The increase pasture dry matter of up to $22 \%$ came at a time of year when farm managers would normally harvest hay or silage and the improved production from biosolids application would result in a monetary benefit to farmers. It is of note that the pasture dry matter produced in Yarra Valley Water biosolids treatments was retarded to some extent by weed infestation.

The third sampling was the start of the 6 week simulated grazing trials. This sampling occurred on July 19, 2005. Compared to the unfertilised control, biosolids applications increased pasture dry matter production at 3.0 and 4.5 NLBAR for South East Water and above 0.5 NLBAR for Yarra Valley Water biosolids, as did inorganic fertiliser $(P<$ $.05)$. There was no significant difference between biosolids treatments and the inorganic fertiliser treatment $(P>.05)$. Compared to the unfertilised control, biosolids treatments resulted in an increase pasture dry matter of up to $32 \%$ at the highest NLBAR rate for Yarra Valley Water biosolids. This increase came at a particularly important time of the year (winter) when pasture growth rates are typically lessened by low soil temperatures and shorter daylight hours, and when farmers have a pasture deficit.

The fourth sampling, after a 6-week growth period following simulated grazing, occurred on November 4, 2005. The application of inorganic fertiliser did not increase pasture production compared to the unfertilised control $(P>.05)$. Compared to the unfertilised control, pasture dry matter production increased in Yarra Valley Water biosolids treatments at 1.0, 3.0 and 4.5 NLBAR by up to $22 \%(P<.05)$.

The fifth sampling occurred on January 24, 2006 and was the only sampling event that occurred in the mid to 


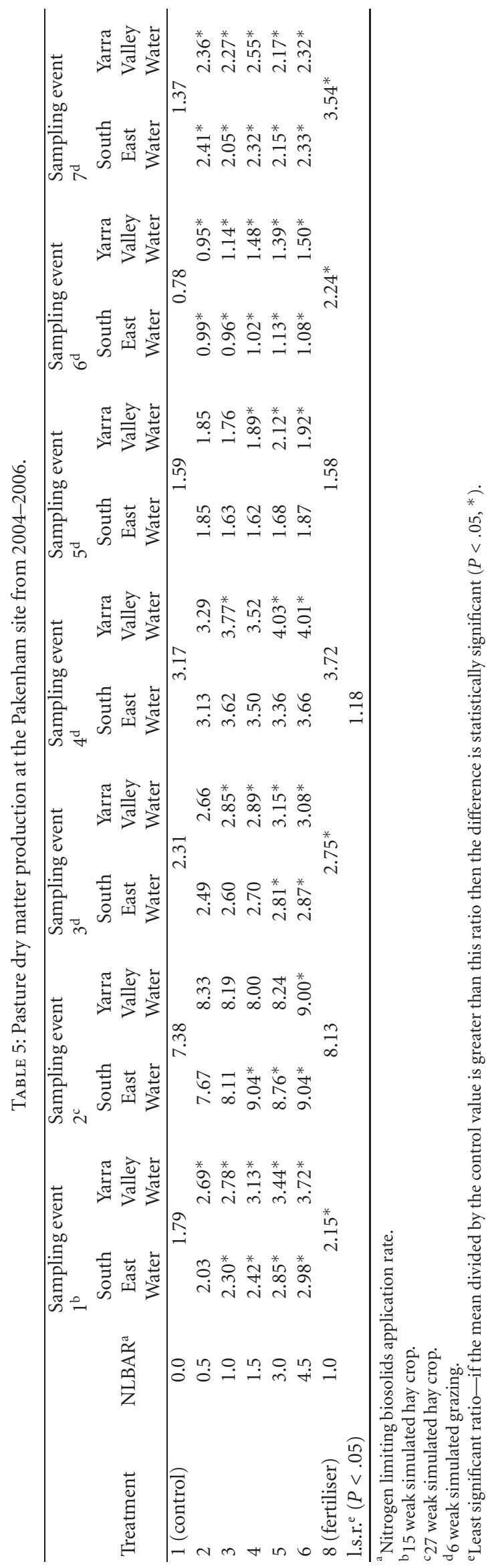


late summer. Compared to the unfertilised control, pasture dry matter increased with Yarra Valley Water biosolids treatments above 1.0 NLBAR $(P<.05)$ by up to $27 \%$, but inorganic fertiliser had no effect $(P>.05)$. This apparent increase in pasture dry matter production in the Yarra Valley Water biosolids treatments is significant for farming operations in the summer months when water is a limiting factor. This increased yield may be related to higher soil $\mathrm{P}$ availability [37] or improved soil physical properties but the precise mechanism responsible for the increased production is unclear.

The sixth sampling occurred on June 20, 2006. The lowest pasture dry matter production was recorded in the unfertilised control $(0.78 \mathrm{t} / \mathrm{ha})$ of any sampling. This coincided with the winter period where low soil temperatures and short daylight hours affect pasture growth. Compared to the unfertilised control, all biosolids treatments increased pasture production (up to $92 \%$ ) as did the application of inorganic fertiliser $(125 \%)(P<.05)$. Biosolids were not as effective at increasing pasture dry matter as inorganic fertiliser $(P<.05)$ although pasture dry matter reached $1.5 \mathrm{t} /$ ha for Yarra Valley Water biosolids at 4.5 NLBAR.

In the final sampling on September 12, 2006, compared to the unfertilised control, biosolids increased pasture dry matter production at all application rates (up to 76\%) as did the inorganic fertiliser treatment by $158 \%(P<.05)$. However, inorganic fertiliser increased pasture production more than any of the biosolids treatments $(P<.05)$. As with the previous two years in spring, increases in pasture dry matter production may increase yields of hay or silage.

Comparing biosolid sources, Yarra Valley Water biosolids increased pasture dry matter compared to that of South East Water biosolids in four out of the seven sampling events (1, 3, 5 and 6) $(P<.05)$. This may in part be explained by higher P content in Yarra Valley Water biosolids (Table 2). In sampling events 2, 4, and 7, there was no difference between pasture dry matter produced by the two different biosolids types. This may have been due to weeds in Yarra Valley Water biosolids plots at the second sampling event and the diminishing effects of biosolids treatments compared to the unfertilised control in sampling event 7.

Analyses of pasture dry matter production over the seven samplings suggests that the effects of biosolids applications diminished over time compared to the inorganic fertiliser treatment which was applied annually. In the first sampling, biosolids increased pasture dry matter compared to the unfertilised control $(P<.05)$, then there was no difference in the next 4 samplings $(P>.05)$. By the last two samplings, pasture dry matter in targeted inorganic fertiliser treatments was higher than the overall pasture production in biosolids treatments $(P<.05)$. Nitrogen in biosolids may be lost through nitrification followed by denitrification or leaching and, therefore, increases in pasture dry matter resulting from added $\mathrm{N}$ in biosolids would be expected to diminish with time

There was no significant difference between the $\mathrm{Cd}$ concentrations in pasture between the unfertilised control and pooled data from all biosolids treatments $(P<.05)$.
The data were pooled as there were no differences $(P<.05)$ between the plant $\mathrm{Cd}$ concentrations of the two biosolids treatments or compared to that of the unfertilised control. For unknown reasons, the $\mathrm{Cd}$ concentrations in pasture were highly variable, especially between sampling dates. There were no significant differences in the concentrations of other metals between treatments.

3.2. Mildura. At Mildura, compared to the unfertilised control, the addition of biosolids from Lower Murray Water resulted in a significant increase in soil $\mathrm{Cu}$ at the two highest NLBAR treatments and soil $\mathrm{Zn}$ at $4.5 \operatorname{NLBAR}(P<.05)$. Again there was a positive linear relationship between $\mathrm{Cd}$, $\mathrm{Cu}$ and $\mathrm{Zn}$ concentrations and biosolids application rates immediately after application with all $r^{2}$ values above 0.80 (Figure 4). All soil concentrations before and after biosolids applications were below the receiving soil contaminant limits (RSCL) of $100 \mathrm{mg} / \mathrm{kg}$ for $\mathrm{Cu}, 200 \mathrm{mg} / \mathrm{kg}$ for $\mathrm{Zn}$ and $1 \mathrm{mg} / \mathrm{kg}$ for Cd [27].

Soil $\mathrm{pH}$ was only measured immediately after biosolids application in 2004 and at harvest in 2005 and 2006 on the unfertilised control and at 4.5 NLBAR and the annual reapplication of 1.5 NLBAR. Compared to the unfertilised control $\left(\mathrm{pH} \mathrm{CaCl}_{2}\right.$ 7.7) biosolids decreased the $\mathrm{pH}(\mathrm{pH}$ $\mathrm{CaCl}_{2} 7.2$ at 4.5 NLBAR) in receiving soils at each sampling $(P<.05)$. This may have been due to the initial $\mathrm{pH}$ of the biosolids being slightly acidic at $\mathrm{pH}$ 6.5.

In general, there was a positive linear relationship between soil $\mathrm{C}, \mathrm{N}, \mathrm{P}$, and Colwell $\mathrm{P}$ concentrations and increasing biosolids application rates at the first sampling perhaps reflecting the low organic matter status of the soil pretreatment. Compared to the unfertilised control (Total C $7.7 \mathrm{~g} / \mathrm{kg}$ ), soil C only increased at 4.5 NLBAR immediately after biosolids applications and above 1.0 NLBAR the following year. Compared to the unfertilised control, after the application of biosolids, $\mathrm{N}$ in the receiving soils increased at the two highest NLBAR treatments and $\mathrm{P}$ increased at all rates above 0.5 NLBAR $(P<.05)$. However, the effects of treatment on soil $\mathrm{P}$ and $\mathrm{N}$ diminished over the two years following biosolids application. The highest Colwell $\mathrm{P}$ was $260 \mathrm{mg} / \mathrm{kg}$ in the $4.5 \mathrm{NBAR}$ treatment, well above recommendations of c.a. 60 for this soil type [36].

The application of biosolids at Mildura also appeared to have little effect on microbial function. Compared to the unfertilised control, SIR was affected only at 4.5 NLBAR and only immediately after biosolids application $(P<.05)$. This apparent decrease in SIR may reflect decreased utilisation of the added substrate (glucose) due to the excessive supply of $\mathrm{C}$ in the 4.5 NLBAR treatment (soil Total C was $19 \mathrm{~g} / \mathrm{kg}$ at 4.5 NLBAR immediately after application). Again, at Mildura, the results of the SIN were equivocal.

Biosolids applications also had little effect on grape production and quality (measured by $\mathrm{pH}$, total acids, brix, phenolics and clarity) (Table 6). Compared to the unfertilised control, grape yield in the first year was not affected by biosolids applications, but in the second year, grape yield was higher in the 3.0 NLBAR and 4.5 NLBAR $(P<.05)$ treatments. Compared to the unfertilised control, 


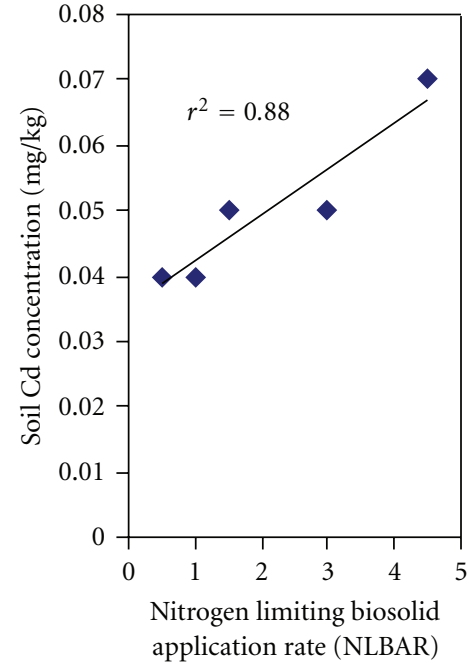

(a)

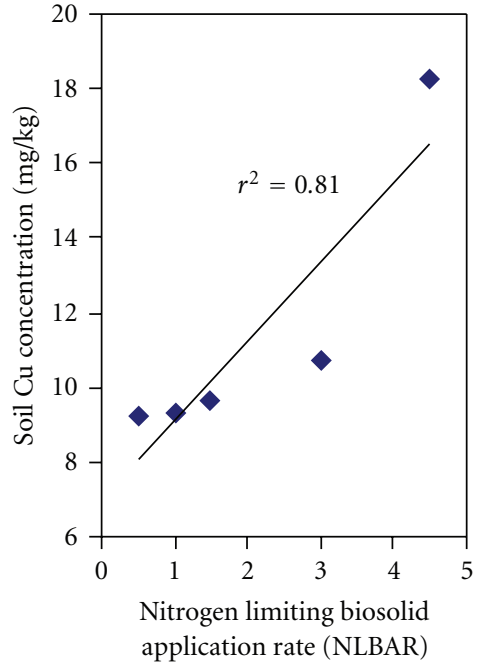

(b)

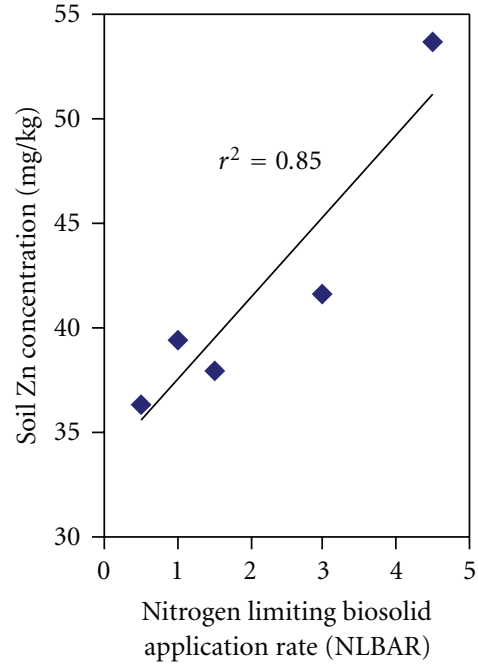

(c)

FIGURE 4: Mean soil total $\mathrm{Cd}, \mathrm{Cu}$, and $\mathrm{Zn}$ concentrations versus biosolids application rates immediately after biosolids were applied at Mildura in 2004.

TABLE 6: Grape yield and grape properties at the Mildura site from 2004 to 2006.

\begin{tabular}{|c|c|c|c|c|c|c|c|c|c|c|c|c|}
\hline \multirow[b]{2}{*}{ NLBAR $^{\mathrm{a}}$} & \multicolumn{2}{|c|}{ Grape yield (t/ha) } & \multicolumn{2}{|c|}{$\mathrm{pH}$} & \multicolumn{2}{|c|}{ Total acids $(\mathrm{g} / \mathrm{L})$} & \multicolumn{2}{|c|}{ Brix } & \multicolumn{2}{|c|}{ Phenolics $^{\mathrm{b}}$} & \multicolumn{2}{|c|}{ Clarity $^{\mathrm{c}}$} \\
\hline & Year 1 & Year 2 & Year 1 & Year 2 & Year 1 & Year 2 & Year 1 & Year 2 & Year 1 & Year 2 & Year 1 & Year 2 \\
\hline 0.0 (control) & 20.8 & 19.0 & 3.84 & 3.87 & 5.17 & 4.52 & 26.2 & 23.8 & 1.35 & 1.19 & 1.20 & 0.90 \\
\hline 0.5 & 20.2 & 18.7 & 3.85 & 3.87 & 5.16 & 4.67 & 26.5 & 23.5 & 1.25 & 1.23 & 1.12 & 0.93 \\
\hline 1.0 & 18.9 & 22.3 & 3.89 & 3.89 & 5.03 & 4.70 & 26.1 & 23.7 & 1.31 & 1.25 & 1.14 & 0.97 \\
\hline 1.5 & 21.8 & 20.0 & 3.84 & 3.88 & 5.34 & 4.79 & 26.5 & 24.0 & 1.36 & 1.24 & 1.30 & 0.99 \\
\hline 3.0 & 17.0 & $24.2^{*}$ & 3.84 & 3.94 & 5.17 & 4.71 & 25.3 & 23.8 & 1.21 & 1.18 & 1.05 & 0.90 \\
\hline 4.5 & 20.5 & $24.6^{*}$ & 3.89 & 3.92 & 5.02 & 4.61 & 25.7 & 23.7 & $1.12^{*}$ & 1.25 & 1.01 & 0.90 \\
\hline $1.5^{\mathrm{d}}$ & 18.7 & 21.3 & 3.92 & 3.91 & 5.15 & 4.84 & 25.9 & 23.3 & 1.36 & 1.06 & 1.20 & 0.74 \\
\hline 1.s. $\mathrm{d}^{\mathrm{e}}$ & \multicolumn{2}{|c|}{4.78} & \multicolumn{2}{|c|}{0.089} & \multicolumn{2}{|c|}{0.51} & \multicolumn{2}{|c|}{1.15} & \multicolumn{2}{|c|}{0.17} & \multicolumn{2}{|c|}{0.20} \\
\hline
\end{tabular}

${ }^{\mathrm{a}}$ Nitrogen limiting biosolid application rate.

${ }^{b}$ Units: absorbance/g of berry weight.

cUnits: (mg anthocyanins/g of berry wt).

${ }^{\mathrm{d}}$ Annual reapplication of biosolids

${ }^{\mathrm{e}}$ Least significant ratio-if the mean divided by the control value is greater than this ratio then the difference is statistically significant $\left(P<.05,{ }^{*}\right)$.

of all the grape quality measures only phenolics increased and this occurred at $4.5 \operatorname{NLBAR}(P<.05)$.

Cadmium uptake in grapes in all years was below the analytical limit of reporting of $0.02 \mathrm{mg} \mathrm{Cd} / \mathrm{kg}$. There is no food standards guideline limit available for $\mathrm{Cd}$ in grapes in Victoria, but the concentrations in grapes were below the food standards guideline concentration of $0.1 \mathrm{mg} / \mathrm{kg}$ for produce such as wheat and rice [38].

\section{Concluding Discussion}

The results from the Pakenham and Mildura sites suggest that biosolids can be applied to pastures and grape vines without adversely affecting soil or plant properties. On the contrary, results from the Pakenham site suggest that biosolids can be used to stimulate pasture production. The monetary benefit of this additional pasture production is difficult to estimate given that it depends on the time of year when the pasture is produced, the costs of alternative feed supplies, and whether the pasture is conserved. However, it is possible to compare the costs of the biosolids and the inorganic fertiliser treatments.

Urea is the most common inorganic $\mathrm{N}$ fertiliser used by farmers in the Pakenham region. The price of urea has varied in recent years from \$500-1250/t (Personnel Communication, Rob Abbottt, Korumberra Lime and Spreading, 26 October 2010) (\$1.09-2.72/kg N). Over the three years of the trial the monetary value of the urea applied to the pastures was estimated to be $\$ 1079-2693$ (plus c. $\$ 40 /$ ha $\times 3=\$ 120$ p.a. application costs). Given that biosolids additions initially increased pasture production relative to inorganic fertiliser, was similar for the next four samplings and was lower in the last two simulated grazings, it is reasonable to conclude that biosolids resulted in similar pasture production over the 
three years to the inorganic fertiliser. It follows that if new pastures were being established, biosolids could be a costeffective alternative to conventional fertilisers if the acquisition, transport, and distribution costs were $<\$ 1000 /$ ha. Interestingly, where biosolids are used commercially in the Barwon region of Victoria transport and spreading costs are estimated to be $<\$ 100 /$ ha.

The potential benefits of applying biosolids to grape vines are more uncertain. Biosolids increased soil $\mathrm{C}$ and one could reasonably assume that would be accompanied by improved soil structural properties [39]. However, these tests were not part of the NBRP. Whether biosolids applications to grape vines are cost effective remains an open question.

While this study suggests that biosolids application may be cost effective from the landholder's point of view, the data from Pakenham and Mildura also point to some broader externalities associated with biosolids use. The total $\mathrm{N}$ applied in biosolids at Pakenham was similar to that applied as inorganic fertiliser (i.e., 449 and $342 \mathrm{~kg} \mathrm{~N} /$ ha for South East Water and Yarra Valley Water, respectively, versus $455 \mathrm{~kg}$ $\mathrm{N} /$ ha for the inorganic fertiliser treatment). However, the release of $\mathrm{N}$ from biosolids during winter when leaching potential is greatest may be of environmental concern. More important are the excessive additions of $\mathrm{P}$ in the biosolids treatments. Maintenance $\mathrm{P}$ fertiliser applications in the Pakenham region are commonly $<50 \mathrm{~kg}$ P/ha [40]. Biosolids applied at 4.5 NLBAR equates to 643,1586 and $706 \mathrm{~kg} \mathrm{P} / \mathrm{ha}$ for South East Water, Yarra Valley Water and Lower Murray Water, respectively. Not surprisingly, the Colwell P for these respective treatments were up to an order of magnitude higher than would be generally considered the agronomic optimum of $60 \mathrm{mg} / \mathrm{kg}$ Colwell $\mathrm{P}$ for these sites [36]. While the incorporation of the biosolids and $\mathrm{P}$ fixation will mitigate the risk of $\mathrm{P}$ exports, where biosolids are applied to pasture, this study would suggest there is a considerable risk of excessive $\mathrm{P}$ exports from sites receiving repeated applications of biosolids or in some cases where biosolids are applied at rates above 1 NLBAR. Perhaps, there is a need to consider a phosphorus limiting biosolids application rate (PLBAR) in addition to an NLBAR when determining appropriate biosolids loadings.

\section{References}

[1] R. L. Swanson, M. L. Bortman, T. P. O'Connor, and H. M. Stanford, "Science, policy and the management of sewage materials. The New York City experience," Marine Pollution Bulletin, vol. 49, no. 9-10, pp. 679-687, 2004.

[2] M. J. Wang, "Land application of sewage sludge in China," Science of the Total Environment, vol. 197, no. 1-3, pp. 149$160,1997$.

[3] F. L. Franklin, "Laboratory tests as a basis for the control of sewage sludge dumping at sea," Marine Pollution Bulletin, vol. 14, no. 6, pp. 217-223, 1983.

[4] D. W. Mackay, W. Halcrow, and I. Thornton, "Sludge dumping in the firth of Clyde," Marine Pollution Bulletin, vol. 3, no. 1, pp. 7-10, 1972.

[5] R. T. Hill, W. L. Straube, A. C. Palmisano, S. L. Gibson, and R. R. Colwell, "Distribution of sewage as indicated by clostridiumperfrigens at a deep-water disposal site after cessation of sewage disposal," Applied and Environmental Microbiology, vol. 62, no. 5, pp. 1741-1746, 1996.

[6] USEPA, Standards for the Use and Disposal of Sewage Sludge; Final Rules, USEPA, Washington, DC, USA, 1993.

[7] S. Gajalakshmi and S. A. Abbasi, "Solid waste management by composting: state of the art," Critical Reviews in Environmental Science and Technology, vol. 38, no. 5, pp. 311-400, 2008.

[8] J. F. Parr, E. Epstein, and G. B. Willson, "Composting sewage sludge for land application," Agriculture and Environment, vol. 4, no. 2, pp. 123-137, 1978.

[9] R. B. Dean and M. J. Suess, "The risk to health of chemicals in sewage sludge applied to land," Waste Management and Research, vol. 3, no. 3, pp. 251-278, 1985.

[10] E. Z. Harrison, S. R. Oakes, M. Hysell, and A. Hay, "Organic chemicals in sewage sludges," Science of the Total Environment, vol. 367, no. 2-3, pp. 481-497, 2006.

[11] M. R. Banerjee, D. L. Burton, and S. Depoe, "Impact of sewage sludge application, on soil biological characteristics," Agriculture, Ecosystems and Environment, vol. 66, no. 3, pp. 241-249, 1997.

[12] I. Sastre, M. A. Vicente, and M. C. Lobo, "Influence of the application of sewage sludges on soil microbial activity," Bioresource Technology, vol. 57, no. 1, pp. 19-23, 1996.

[13] L. Vasseur, C. Cloutier, and C. Ansseau, "Effects of repeated sewage sludge application on plant community diversity and structure under agricultural field conditions on Podzolic soils in eastern Quebec," Agriculture, Ecosystems and Environment, vol. 81, no. 3, pp. 209-216, 2000.

[14] J. W. Brendecke, R. D. Axelson, and I. L. Pepper, "Soil microbial activity as an indicator of soil fertility: long-term effects of municipal sewage sludge on an arid soil," Soil Biology and Biochemistry, vol. 25, no. 6, pp. 751-758, 1993.

[15] J. S. Angle, S. P. McGrath, A. M. Chaudri, R. L. Chaney, and K. E. Giller, "Inoculation effects on legumes grown in soil previously treated with sewage sludge," Soil Biology and Biochemistry, vol. 25, no. 5, pp. 575-580, 1993.

[16] I. Koomen, S. P. McGram, and K. E. Giller, "Mycorrhizal infection of clover is delayed in soils contaminated with heavy metals from past sewage sludge applications," Soil Biology and Biochemistry, vol. 22, no. 6, pp. 871-873, 1990.

[17] M. J. McLaughlin, M. St. J. Warne, D. P. Stevens et al., "Australia's National Biosolid Research Program-how it came about, and what has it discovered?" Water Practice and Technology, vol. 2, no. 4, article 88, 2007.

[18] K. Broos, M. ST. J. Warne, D. A. Heemsbergen et al., "Soil factors controlling the toxicity of copper and zinc to microbial processes in Australian soils," Environmental Toxicology and Chemistry, vol. 26, no. 4, pp. 583-590, 2007.

[19] M. ST. J. Warne, D. Heemsbergen, M. McLaughlin et al., "Models for the field-based toxicity of copper and zinc salts to wheat in 11 Australian soils and comparison to laboratorybased models," Environmental Pollution, vol. 156, no. 3, pp. 707-714, 2008.

[20] M. ST. J. Warne, D. Heemsbergen, D. Stevens et al., "Modeling the toxicity of copper and zinc salts to wheat in 14 soils," Environmental Toxicology and Chemistry, vol. 27, no. 4, pp. 786-792, 2008.

[21] M. J. McLaughlin, M. Whatmuff, M. Warne et al., "A field investigation of solubility and food chain accumulation of biosolid-cadmium across diverse soil types," Environmental Chemistry, vol. 3, no. 6, pp. 428-432, 2006.

[22] D. A. Heemsbergen, M. J. McLaughlin, M. Whatmuff et al., "Bioavailability of zinc and copper in biosolids compared to 
their soluble salts," Environmental Pollution, vol. 158, no. 5, pp. 1907-1915, 2010.

[23] D. A. Heemsbergen, M. ST. J. Warne, K. Broos et al., "Application of phytotoxicity data to a new Australian soil quality guideline framework for biosolids," Science of the Total Environment, vol. 407, no. 8, pp. 2546-2556, 2009.

[24] N. Korboulewsky, S. Dupouyet, and G. Bonin, "Environmental risks of applying sewage sludge compost to vineyards: carbon, heavy metals, nitrogen, and phosphorus accumulation," Journal of Environmental Quality, vol. 31, no. 5, pp. 15221527, 2002.

[25] R. F. Isbell, Australian Soil Classification, CSIRO, Melbourne, Australia, 2nd edition, 2002.

[26] G. E. Rayment and F. R. Higginson, Australian Laboratory Handbook of Soil and Water Chemical Methods, Inkata Press, Melbourne, Australia, 1992.

[27] EPA Victoria, Guidelines for Environmental Management: Biosolids Land Application, EPA Victoria, Southbank, UK, 2004.

[28] B. A. Zarcinas, B. Cartwright, and L. R. Spouncer, "Nitric acid digestion and multi-element analysis of plant material by inductively coupled plasma spectrometry," Communications in Soil Science and Plant Analysis, vol. 18, no. 1, pp. 131-146, 1987.

[29] B. A. Zarcinas, M. J. McLaughlin, and M. K. Smart, "The effect of acid digestion technique on the performance of nebulization systems used in inductively coupled plasma spectrometry," Communications in Soil Science and Plant Analysis, vol. 27, no. 5-8, pp. 1331-1354, 1996.

[30] P. Iland, N. Bruer, G. Edwards, S. Weeks, and E. Wilkes, Chemical Analysis of Grapes and Wine: Techniques and Concepts, Patrick Iland Wine Promotions Pty, Adelaide, Australia, 2004.

[31] D. L. Sparks et al., Methods of Soil Analysis_Part 3 Chemical Methods, edited by D. L. Sparks, Soil Science Society of America, no. 5, American Society of Agronomy, Crop Science Society of America and Soil Science Society of America, Madison, Wis, USA, 1st edition, 1996.

[32] OECD, OECD Guidelines for Testing of Chemicals. Soil MicroOrganisms: Nitrogen Transformation test and Carbon Transformation Test, Paris, France, 2000.

[33] E. Smolders, K. Brans, F. Coppens, and R. Merckx, "Potential nitrification rate as a tool for screening toxicity in metalcontaminated soils," Environmental Toxicology and Chemistry, vol. 20, no. 11, pp. 2469-2474, 2001.

[34] GenStat, GenStat for Windows. Release 9.1, VSN International, Hemel Hempstead, UK, 2007.

[35] M. Suhadolc, R. Schroll, A. Hagn, U. Dörfler, M. Schloter, and F. Lobnik, "Single application of sewage sludge-impact on the quality of an alluvial agricultural soil," Chemosphere, vol. 81, no. 11, pp. 1536-1543, 2010.

[36] K. I. Peverill, L. A. Sparrow, and D. J. Reuter, Eds., Soils Analysis: An Interpretation Manual, CSIRO, Collingwood, Australia, 1999.

[37] D. K. Singh and P. W. G. Sale, "Subsoil phosphorus concentration and tolerance of heavily grazed legume-based pastures to dry soil conditions," Wool Technology and Sheep Breeding, vol. 50, no. 3, pp. 499-502, 2002.

[38] FSANZ, Australia and New Zealand Food Standards Code. Incorporating up to including amendments 80 , edited by F. S. A. Zealand, Anstat. Pty, Canberra, Australia, 2005.

[39] E. W. Russell, Soil Conditions and Plant Growth, Longman, 10th edition, 1973 .
[40] Department of Primary Industries, Fertilising Dairy Pastures, Victorian State Government, Melbourne, Australia, 2nd edition, 2005. 

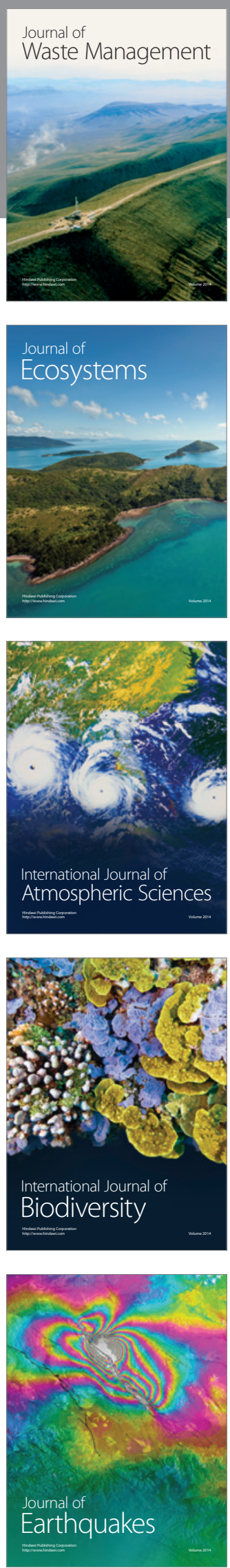
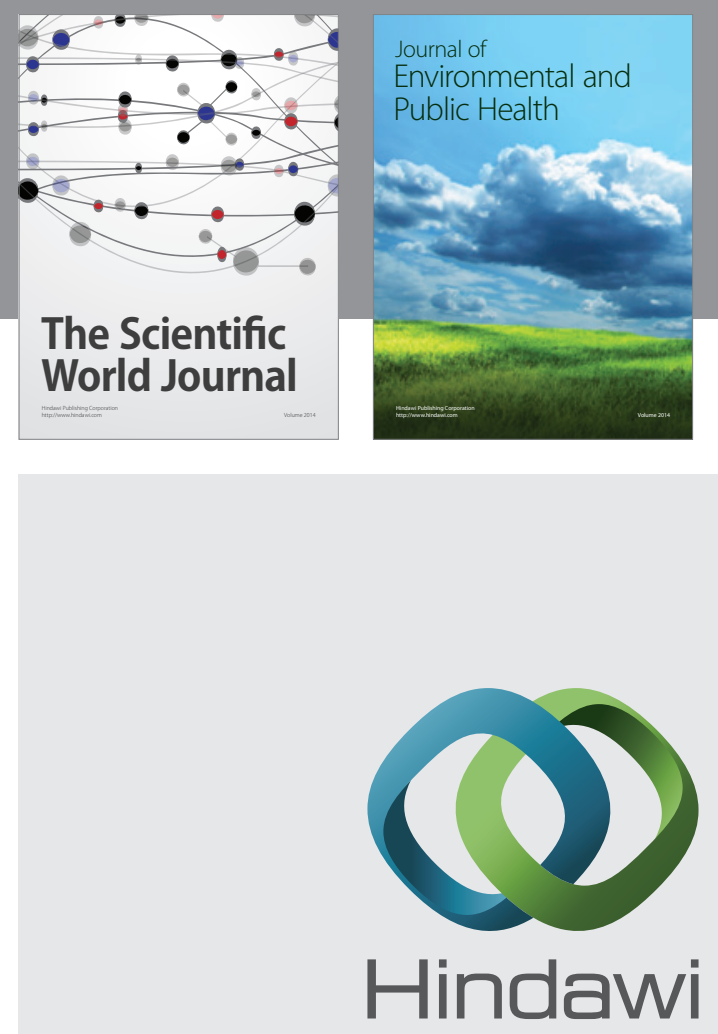

Submit your manuscripts at

http://www.hindawi.com
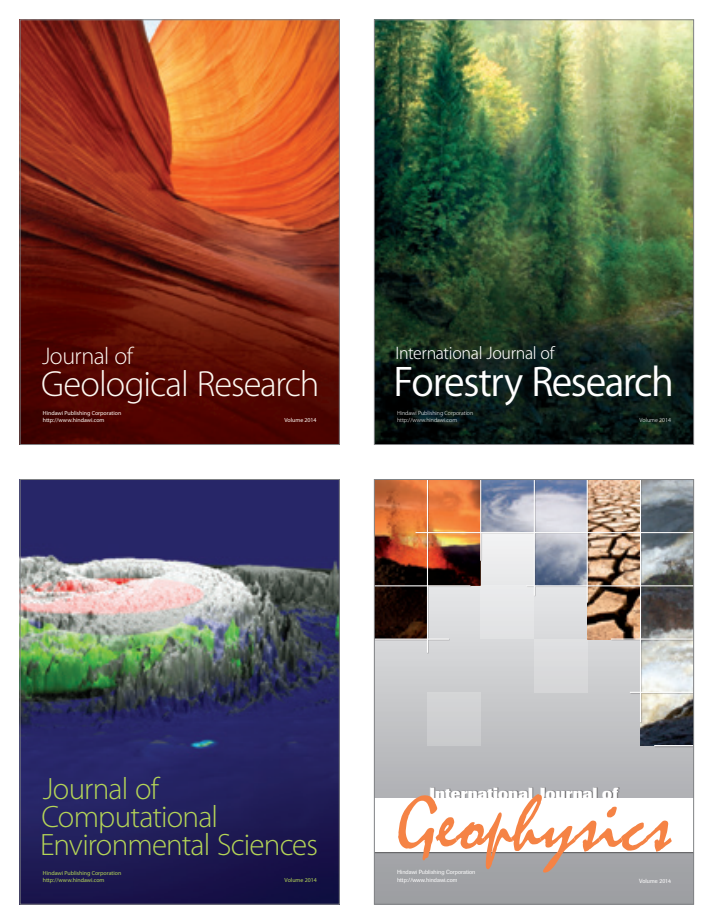
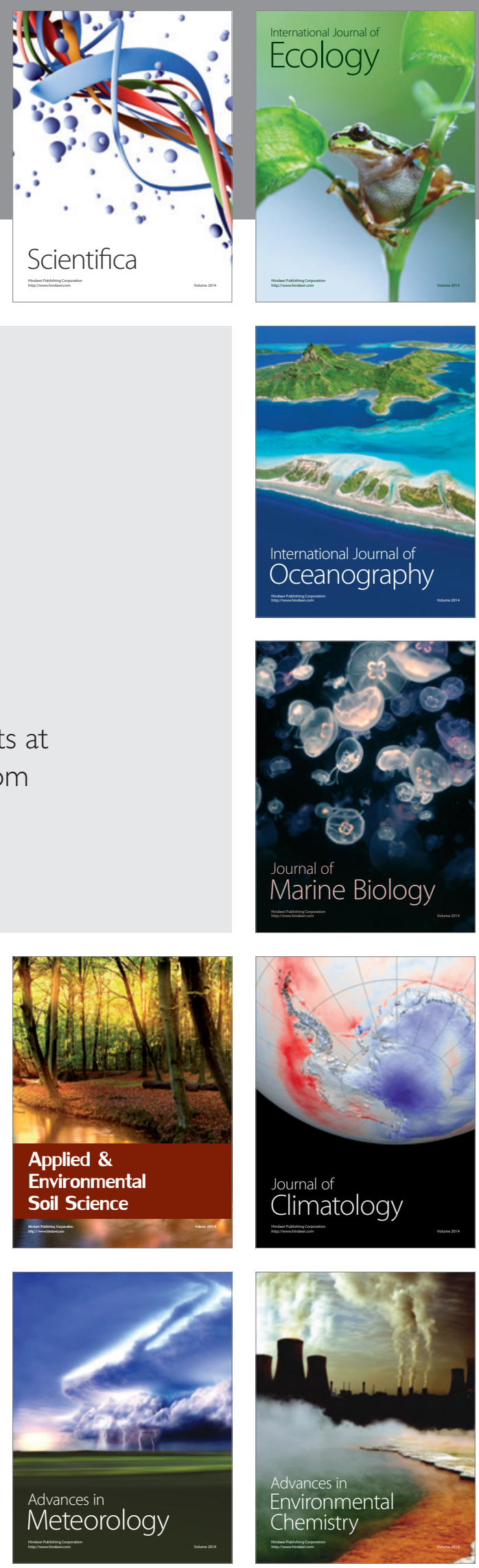